\title{
Negative Phenomena in Social Sphere of Miners' Towns and Settlements during Transition to Market Economy (1992-1999)
}

\author{
Igor S. Solovenko ${ }^{\mathrm{a}}$, Tatiana S. Kust ${ }^{\mathrm{a} *}$, Petr P. Rumyantsev ${ }^{\mathrm{b}}$ \\ * Corresponding author: tatjana.kust@yandex.ru \\ ${ }^{a}$ Yurga Institute of Technology, TPU affiliate, 26, Leningradskaya str., Yurga, Russia, E-mail: solovenko71@mail.ru \\ ${ }^{b}$ Tomsk State University, 36, Lenina ave., Tomsk, Russia, E-mail: petroom@mail.ru
}

\begin{abstract}
http://dx.doi.org/10.15405/epsbs.2016.02.9

The authors of the paper deal with preconditions, dynamics, substance and characteristics of negative phenomena in social sphere of miners' towns and settlements under market transformations. Both common and local social problems of coal-mining regions are shown gradually, as well as reasons for their growth and decline. Specific facts emphasizing hard living conditions of population in miners' towns and settlements are submitted. The authors think they were much worse than at the end of soviet period. The correlation of social problems and high protest activity is considered. The conclusion is drawn that financial conditions of miners were hard because the state didn't influence on economic situation in the country and implement restructuring of coal-mining industry. They didn't have an opportunity to solve all socially significant problems and the state couldn't provide them with a mechanism of support. Poverty and unemployment were key problems of miners. On one hand, they facilitated protest activity. On the other hand, they restrained it, because miners and their families were exposed to risk to obtain no assistance for solution of their social-economic problems. That is why protests of miners were chaotic, local and caused different response of the society to them.
\end{abstract}

C 2016 Published by Future Academy www.FutureAcademy.org.uk

Keywords: Russia; miners; protests; social problems; market transformations.

\section{Introduction}

The most part of population in Russia suffered from the same difficulties caused by the shock therapy as workers in miners' towns and settlements. Their struggle for social and economic interests wasn't so pronounced though. It was quite logical, that both political factors and problems in mining industry and difficult social conditions in coal producing regions influenced on the high level of protest activity of miners. 
Social problems of miners' towns and settlements in 1990-s were consequences of growing crisis, which rooted in the soviet period. This fact was demonstrated by mass strikes in 1989, when such socially vital questions were raised by miners as providing them with essential commodities, relocation from dilapidated accommodation, environmental problems etc. The leaders of miners' movement hoped the change in political and economic systems to make workers' conditions better. While addressing to people they often mentioned well-developed capitalist states and emphasized all people lived in good conditions there. Meanwhile, oppositionists forgot the difficulties the Western countries had to overcome developing social market economy, and assuring the wellbeing of all their citizens. The main point of leaders of miners' movement was fighting against communist regime. Social problems of miners were of secondary importance for them in spite of statements like "it is necessary to develop a social program to protect an individual from market economic situation" (Golikov, 1990 $\&$ State records...). The transition to market and protection of the most affected group of miners' population from it was not performed in the Soviet period.

The ideas of soviet workers to build a consumer society were disillusioned by the difficulties of transition period in 1990-s. The government of the Russian Federation began to develop a new social policy directed at development of a liberal mechanism in economy and policy. The President B. Yeltsin promised to make Russians wealthy and happy in a couple of years. However, it wasn't implemented, radical liberal reforms facilitated realization of social and economic interests of a small part of Russians. The greatest part of workers including miners lived in bigger poverty than in Soviet crisis times. On account of various reasons (first of all, dynamic character of crisis in coal producing industry) social problems of miner's towns and settlements evolve gradually.

\section{The first phase $(1992-1996)$}

The first phase (1992-1999) of transition to market relations was distinguished by such negative phenomena in social sphere of miners' towns and settlements as: worsening living standards of population, growing professional and social illnesses, unemployment, dissemination of crime, degradation of social infrastructure and deforming social and professional structure of miners' community.

Since January 1992 worsening living standards were caused by inflation, which shattered social stability in coal producing regions. Rising prices were more dynamical in miners' towns and settlements, so they had more significant influence on social processes than in other regions, because increasingly falling volumes of mined coal made workers even more vulnerable. Furthermore, industrial regions seriously depended on supply of food commodities and consumer goods from other regions; and that was an objective reason their final cost rose. The lack of cash resources and growth of offset debts led to increasing real liabilities and worsening living standards, because the prices for goods in shops of mines were, as a rule, higher as the market ones. No wonder, that in May 1992 Kemerovo region was in the top ten of regions with the highest prices. Their growth was $20 \%$ a week (State records...). Therefore, inflation both destabilized economic activity of coal-mining enterprises and had a serious effect on living standards of population in miners' towns and settlements. 
http://dx.doi.org/10.15405/epsbs.2016.02.9

eISSN: 2357-1330 / Corresponding Author: Tatiana S. Kust.E-mail: tatjana.kust@yandex.ru

Selection and peer-review under responsibility of the Organizing Committee of the conference

Uncontrolled growth of prices in condition of insufficient social protection distinguished inefficient policy of authorities and was an important argument for evolving protest movement.

The situation could be improved via increasing of miners' salary and implementation of programs to provide social support to population of miners' towns and settlements. Moreover, some subjective and objective prerequisites to take these measures were available. In the first years of shock therapy the President B. Yeltsin considered miners to be social and political support of a new power. The level of their salary and the degree of belated payment of the earned money seemed to be better than those of other categories of workers, especially in 1992. However, within the period under consideration the salary of workers in some industries and enterprises left behind the remuneration of miners' labor, which was delayed and didn't keep pace with inflation.

The situation was worsened by differently disseminating problems in coal-mining industry, which caused uneven level of salary of workers at different enterprises, as well as in miners' towns and settlements. The workers engaged at open-pit mines had higher salary, as the rule, and were in best conditions. People in single-profiled settlements, that is, coal producing enterprises predominated in the general structure of economy had the lowest wages. One had difficulties finding another job, and miners had to migrate or had a rough time.

As the result, the level of salary and real cash incomes of miners were steadily decreasing. All obtained money was spent in miners' families mostly on purchasing food commodities and consumer goods. They couldn't afford buying quality goods and services. The experts emphasized the miserable living conditions of miners' families, the necessity of their financial support by the state (Bisyukov, 1995). But the authorities were not able to response to these claims efficiently.

Falling living standards of miners caused worsening of their nutrition, medical servicing and decreasing prestige of the profession. It had the worst consequences for nutrition of workers. In the period of time under consideration the biggest part of population in coal-mining regions consumed more bread and potatoes, but far less meat and dairy products, as well as fish, fruit and vegetables (Regions of Russia, 2000). Population of miners' territories located behind the Polar circle had the poorest food supply, as people had no gardens or kitchen gardens there.

The low caloric value of food, lack of vitamins and animal protein in food allowance caused decreasing efficiency of workers, as the consequence, their salary and living standards fell. The workers, working under the earth surface and having big physical loads had the most difficult conditions.

The social programs to support miners' families were not sufficient. Growing deficiency of state budget didn't allow resolving of socially important problems of coal-miners and even keeping the level of protection they had at the beginning of the period under consideration. Sometimes the mine wasn't officially closed but put out of service. That meant social measures could be taken in an uncertain period of time (Bisyukov, 2000). Federal and local authorities could postpone resolving miners' problems. As the result, social support was reduced mainly to provision with unemployment allowances, but local employment authorities were short in assets for this purpose. The government of the Russian Federation didn't have a wide-scale and detailed plan of social support of miners, like that 
in Poland (Popov \& Rozhkov, 2000), so population of miners' towns and settlements was in conditions of natural selection.

Malnutrition, low caloric value of food, insufficient quantity of vitamin products as well as worsening environment and medical services provided to population, frequent actions of protest (especially hunger and underground strikes) caused growing professional and social illnesses. At the same time coal production was distinguished by harder, more harmful and dangerous work conditions as if compared with other branches of industry (Rossikhin, 1998). It was the first-ranked industry among all branches in terms of professional illnesses of workers, their injury rates, including the lethal ones.

Outdating equipment and its unreasonable wear were the main reasons of industrial accidents and other illnesses, as well as causa mortis. There was no money available to purchase new equipment and machinery; that is why accidents at mines were a quite ordinary phenomenon. Moreover, in conditions of market competition the staff of coal-mining enterprises didn't pay special attention to ordinary requirements for technical safety in the mine, as well as didn't respond to prohibitions to organize underground protest actions, take preventive measures and diagnose professional illnesses. 280 miners died in 1997 only (Leskova \& Tolstikov, 1998).

Wide-spreading alcohol and drug abuse also had an effect on high rates of socially significant illnesses, as well as difficult environment conditions in miners' regions. The crisis of morality can't be overestimated, which was evolving in the country at that time. No wonder, that such socially significant illnesses as tuberculosis, syphilis and AIDS were the most concerning. The scales of their dissemination were unprecedented and caused serious anxiety of experts.

Miners got angry because of illnesses and frequent deaths, aggressive at work and in daily life while struggling for their rights and social-economic interests. They were not afraid to claim openly, they had lost everything and were ready to carry out their struggle to its conclusion.

Over the first stage miners' community faced a problem of unemployment they hadn't known before. The latter was caused by the character of re-structurization of coal-mining industry, which was mainly reduced to putting down many commercially unviable enterprises, so a great number of workers got unemployed. Over the period 1994-1997 approximately 85 thousand employees were discharged (Bogopolsky \& Klimov et al., 1999). Dozens of thousands of workers were dismissed when non-core enterprises were excluded from the branch. The most significant reduction of working staff was carried out in Rostov and Kemerovo regions when unprofitable and unviable enterprises were put down (State records...).

World history had already known the layoffs of workers during the conversion of coal-mining industry. However, the level of unpreparedness for it in Russia exceeded all pessimist forecasts because of a number of subjective and objective reasons. Among objective reasons for inefficient resolving the problem of miners' employment the following ones can be mentioned: 1) mono-profile character of the most miners' towns and settlements; 2) deficient financial resources in local and regional budgets; 3) lack of special agencies to train the unemployed and create new jobs; 4) low level of investment into production infrastructure; 5) belated fulfillment of social commitments by the government of the Russian Federation, foreseen in feasibility studies of put down mines; 6) crisis conditions on other 
http://dx.doi.org/10.15405/epsbs.2016.02.9

eISSN: 2357-1330 / Corresponding Author: Tatiana S. Kust.E-mail: tatjana.kust@yandex.ru

Selection and peer-review under responsibility of the Organizing Committee of the conference

branches of economy; 7) unattractive conditions of business activities (peripheral character, scarcity of financial resources etc.).

There were also subjective reasons of growing unemployment among the miners. Regular workers of coal-mining industry found it difficult to get adapted to conditions of work in other branches of economy and to be trained in new professions (State records...). A lot of experts dealing with coalmining industry said miners didn't agree even to work at the plants. There was an old "soviet" attitude to their heroic profession in their unconsciousness. "Working elite" couldn't realize why they had to look for other jobs, earn less, lose their social benefits etc. At the same time, Russian sociologists noted that nearly a half of those who had been asked didn't agree to change their jobs. A small percentage of them were ready to move to other cities, even if they were provided with a new job in other mine (Bisyukov et al, 1994). And it wasn't a specific feature of Russian miners' behavior. The first phase was the most difficult period for miners' adaptation to new social-economic conditions.

Since 1994 unemployment increased in miners' regions because of insufficient mechanism of miners' employment. Here, it is to note that officially registered unemployment was several times smaller than its real level because of not being recorded and other reasons, as well as lower than the level determined according to methods of International Labor Organization (Pyatkin, 2005).

The highest unrecorded unemployment due to restructuring of coal-mining industry was typical especially for small miners' regions. However, in terms of mass social instability, unemployment was the most critical in top coal-mining regions of the country - Kuzbass, Eastern Donbas and Pechora coal-mining basin. At the end of the period under consideration the number of miners without jobs grew steadily, and caused anxiety even for the Government of the Russian Federation (State records).

Each miner facing the possibility to lose the job was demoralized; especially women who had no chance to find a job after the mine had been put down. Therefore, the demands for ensuring a job were always in the list of complaints to governments and authorities.

Poverty and hopelessness provoked dissemination of crime in miners' towns and settlements. Rapidly growing number of crimes was typical for all regions of the Russian Federation; it was the consequence of strained social-economic problems. Moreover, barriers to crime dissemination typical for the soviet period (commissions to struggle against alcohol abuse, community courts, preventive committees etc.) stopped existing. Miners' towns and settlements appeared to be susceptible to crime dissemination. Worse social and economic conditions as if compared with other regions of the Russian Federation facilitated crime dissemination. On the other hand, "criminal past" of many coal-mining enterprises caused it and conciliated behavior attitudes of miners' towns and settlements population with the sub-culture of criminal representatives. It was quite logical that the first phase was distinguished by difficult criminal situation in all coal-mining regions. Thefts, burglaries, robberies were prevailing in miners' towns and settlements against other crimes and became quite a common phenomenon. The biggest concern in the society was made by rapidly growing death-rate caused by murders (State records...). Social justice in the society was undermined and miners were oriented towards the independent struggle.

The problem of degrading social infrastructure in miners' towns and settlements was of the same importance during the first phase. Coal-mining rates influenced on living conditions of 64 miners' 
towns and 76 big urban-type settlements, as well as 800 near-mine settlements (Kozhukhovsky, 1999). Therefore, activity of coal-miners had an effect on living conditions of millions of people. In the early 1990-s social infrastructure of miners' regions suffered from a deep crisis, which had a negative effect both on everyday life of population and future of coal-mining industry.

In fact, a lot of objects of life activities required for special attention over the before-going decades. But nobody expected the rates of worsening of their functions had been so fast, as the consequence, life and living standards of people were badly affected. New authorities demonstrated a neglectful attitude to everything soviet miners were proud of - high standards of medical services, wide opportunities of sanatorium-and-spa-treatment, best cultural and social facilities. Worsening conditions of coal-mining industry automatically had a negative effect on stability in this sphere of life. Degradation of social infrastructure in miners' towns and settlements had a gradual character, that's why population wasn't seriously concerned about it at first. Soviet safety factor made it possible them keep stability and withstand to protest attitudes of miners. But soviet reserves were over; the new ones were not created because the state support of social sphere was insufficient (State records...). Privatized enterprises didn't let hopes come true. Their managers didn't want to take care about social infrastructure, whereas governments and authorities didn't even make an attempt to let them do it.

The degradation in social infrastructure of miners' towns and settlements had such negative forms of manifestation as increasing slum and dangerous structures, reducing building and reconstructing schools, hospitals, roads, bridges and other socially significant objects. Low rates of resettlement from slum and dangerous accommodation including those located in mining leases were the most concerning issues. These issues made miners angry; let them find the social and economic policy of the government unacceptable, undermined the President's authority.

Deformations in social and professional structure of miners' community were the results of growing problems at the end of the first period. Potential opportunities provided by executive authorities of the country to miners were steadily reduced. Worsening macroeconomic situation let the government of the Russian Federation both reduce expenditures on social and economic support of coal-mining regions and even not carry out the before-made social assignments. Deformations in social and professional structure of miners' community were the most evident. Poverty, unemployment and other social problems of coal-mining regions caused aging of staff, disappearing professional knowledge and skills, growing rates of youth migration, etc, as the result, miners lost their position in social and professional structure of Russian society.

The youth didn't want to be employed at the mines; that was the most significant fact. A lot of young men and women left miners' towns and hoped to find a job in bigger and more perspective human settlements of their regions and even in distant areas of the country. The high risk to lose a job made the youth look for a more stable source of incomes. That is why, since the early 1990-s a lot of young men stopped working at the enterprises without waiting for being discharged. It harmed social and economic structure of coal-mining industry staff, caused aging of workers. On account of retired workers engaged in underground and open mines Kemerovo region was the most distinguished one (State records ...). 
http://dx.doi.org/10.15405/epsbs.2016.02.9

eISSN: 2357-1330 / Corresponding Author: Tatiana S. Kust.E-mail: tatjana.kust@yandex.ru

Selection and peer-review under responsibility of the Organizing Committee of the conference

"Aging" of mining staff was also caused by failures in the system of training of well-qualified working staff and engineers. Leading mines and open-pit mines cut financial support to colleges and training centers, restricted students to obtain practical skills. Put down coal-mining enterprises and their weakness were the reasons some educational institutions majoring in training miners were closed. The number of graduates from the institutions of primary professional education majoring in mining industry steadily fell in the country (Social conditions..., 2003). Worsening qualification of young workers was even a more negative consequence.

Falling authority of miner's profession, as well as dynamically decreasing number of its representatives were vital questions for miners so they put in claims the branch-relevant issues.

In general, worsening living standards in miners' towns and settlements were rather foreseen results of shock therapy during the first stage. Decreasing level of life-support of miners had a negative impact on their professional status and increased marginalization of the biggest social group in the working class of the country. In the coal-mining regions distinguished by the most difficult situation in the social sphere, there were protests oriented at radical forms of struggle, which were hold more frequently. The growing political tension in miners' towns and settlements in 1996 - 1997 was frightening to become uncontrolled at any time.

\section{The second phase (1997 - 1998, July)}

Over the second period (January - July 1998) critical conditions were typical for the whole country. The research conducted at that time demonstrated people were more concerned about social problems than by economic ones (Kazva, 2002). Social conditions were dynamically getting worse. Among them the worst ones were poverty, unemployment, and resettlement of people from the North and areas equated to it.

In the period under consideration it was poverty that made miners' families worry. All other problems of miners got the second-ranked ones. Inflation and falling incomes were as typical for the second period as for the first one. At the same time arrears in payment were as significant as no-when before (sometimes up to 14 moths). In total, all these negative processes acquired a dynamic and topical character determining the misery of workers.

Low incomes of workers were typical for those towns, which suffered most from negative consequences of coal-mining industry restructuring. In the structure of cash expenditures of population in miners' regions those to buy goods and services were steadily reduced. The workers of coal-mining enterprises saved themselves by means of small holdings, part-time jobs, old-age pension payments of their grandparents, as well as by money of trade unions, provided to the neediest ones. The most urgent problems couldn't be solved though. The society got socially differentiated and impoverishment of workers in coal-mining industry was getting more and more appreciable; creating additional threat to national security of Russia (Sturba, 2009).

In general, the state couldn't develop sufficient mechanisms to overcome poverty of miners' families. It had a direct impact on dissemination of illnesses and crime among miners. The question of "chasm of poverty and misery" was often raised in local papers, and evoked a warm response of all people living in miners' regions. Therefore, conditions were created for collective protests of workers 
eISSN: 2357-1330

Selection \& Peer-review under responsibility of the Conference Organization Committee

engaged in various industries.

Financial and economic crisis, mines, which were steadily put down without preliminary assured work places, as well as significant flow of migrants caused increasing unemployment in coal-mining regions. The great number of employees in put down mines was not satisfied with liquidation of their enterprises and didn't concern about other, often more important problems, even those like salary, conditions and safety of work (Pyatkin, 2005). A lot of miners hoping to have a work place had to undergo both low salary and arrears of wages.

Significant financial expenditures were foreseen in the plan of mining industry restructuring in Russia, including assistance from international financial organizations, to create new places of work. However, redundant miners didn't obtain the most of those planned financial recourses, they were stolen or misused. New places of work were created very slowly, the plans were not met, and all retraining measures were taken as pilot drafts only (Harte, 2003).

As the result the rates of unemployment were very high, especially in large coal-mining regions of the country. The worst thing was that the young made the most significant share of the unemployed. Unemployment, in its turn, led to growing poverty and criminalization of the society, and made miners unsure in their future life.

Social problems of miners were relevant both for Russia on the whole and had their regional peculiarities. One of the specific problems was that of resettlement of population from the North and areas equated to it. Additional social and economic support for Northern regions, provided in the soviet times, was reduced up to its minimum because of deficient financial resources. For instance, at the beginning of the first phase the program to resettle the population from the Northern areas was implemented, but during the second phase it was practically blocked despite B. Yeltsin's promises before the elections.

Distantly located Northern towns and settlements had difficulties in resolving such burning problems as unemployment, inflation, high rates of illnesses etc. Nearly all mines, located in the North were unprofitable because of low prices and high self-cost of coal. As the consequence, they were to put down. A great number of miners and local residents were to be resettled, provided with accommodation and be employed. The most of them lived in Pechora coal basin.

Although miners often reminded the President of Russia not to keep his own promises, federal executive authorities didn't take any measures to resolve the problems of people living in the North. Some episodic resettlement of residents from Inta and Vorkuta in other regions of the country didn't principally change the situation. Therefore, all miners were dissatisfied, as the result, miners' protests became more active in Pechora coal basin over the period under consideration.

In general, the second phase was the most difficult. Coal-mining industry restructuring was attended by numerous faults and errors, which caused significant worsening of miners' living standards, falling of their social prestige and status. The main negative result of worsening social problems regarded high rates of natural population loss in coal-mining regions, as well as migration of the young in more economically attractive regions and cities of the Russian Federation. The disastrous living standards of miners and their families aroused a fair indignation of all people living in miners' regions, let them resist to unpopular methods of shock therapy. 
http://dx.doi.org/10.15405/epsbs.2016.02.9

eISSN: 2357-1330 / Corresponding Author: Tatiana S.Kust.E-mail: tatjana.kust@yandex.ru

Selection and peer-review under responsibility of the Organizing Committee of the conference

\section{The third phase (August 1998 - 1999)}

The third phase (August 1998 - 1999) was distinguished by the negative character of social life in miners' towns and settlements. Meanwhile, at the beginning of this phase some destructive factors worsening social and economic instability in coal-mining regions added to the inertia in resolving of existing problems. Among them financial default and governmental crisis are worth mentioning, as well as ongoing arrears of wages. They blocked effective struggling against negative social phenomena in miners' towns and settlements. During the third phase miners had similar key problems as during the second phase: poverty, unemployment, and resettlement of people from the Northern regions and areas equated to them.

Poverty remained being the core problem in miners' families. Financial default, evolving at the beginning of the period under consideration caused rapidly worsening macroeconomic conditions in the country and as the result, living standards of population in miners' towns and settlements. Arising inflation after default, low salaries and huge arrears of wages caused significant decrease in real incomes of population in coal-mining regions, as the consequence, consumption of goods and services was cut down. Local and regional budgets couldn't provide support even to the poorest ones. The governments and authorities also didn't provide necessary support to miners and their families, because governmental crisis evolved after the default and nobody could solve problems of population.

Miserable living standards of miners' families were caused by low wages and enormous arrears of them. The situation was different because the crisis of wages had a local character and arrears were completely the consequence of coal consumers' behavior, whereas coal-mining enterprises were selfresponsible for the relations with them.

The problem of unemployment was hardly solved during the third phase in spite of macroeconomic stabilization. The governmental crisis in August 1998 stopped positively evolving dynamics of providing redundant miners with places of work. Redundant miners had few opportunities to be employed because new businesses weren't founded after default and unprofitable coal-mining enterprises were put down. Although the governments and authorities took some successful measures in 1999 this issue was an urgent one in the period under consideration. Officially registered unemployment was high even in top coal-mining regions in 1999 (Regions..., 2001) and made both population and authorities concern about it.

Up to the end of period under consideration the local but burning problem of resettlement people from the Northern regions and areas equated to them wasn't solved completely. Residents of Pechora coal basis suffered most of all. 100 thousand people were to be resettled from Vorkuta und Inta in autumn 1998 (Shadrin, 1998). Implementation if this task was directly dependent on transfers from federal budgets, which was deficient at the beginning of the period under consideration. In 1999 coalmining industry obtained more financing from the budget and a complex of various social programs was implemented and directed at needs of miners' regions residents, so resettlement of people from the Northern regions began. However, not everybody who wanted to move to central regions of Russia was able to do it because mines were put down and the problem required for significant financial support. Over the last year under consideration nearly 40 thousands people were waiting to be resettled from the Northern regions, among them 6.2 families because of enterprise liquidation (Salamatin, 1999). 
In general, the third phase made the influence of negative factors on social sphere of miners' towns and settlements less significant. It facilitated localization and latent transformation of many topical problems in miners' regions, as the consequence, open protests of miners were reduced.

\section{Conclusion}

To draw a conclusion, miners' financial conditions were hard because the state didn't have a considerable impact on economic activities and implement restructuring of coal-mining industry in 1992-1999. Miners couldn't solve all socially significant problems, and the state didn't have a mechanism to support them. Poverty and unemployment were key problems of miners. On one hand, they furthered protests; on the other hand they withstood them because miners and their families were exposed to risk to face their social and economic problems. That is why, protests were chaotic and local, and the society had different responses to them.

\section{Acknowledgements}

The authors would like to thank the anonymous referees for their constructive and useful comments on the paper.

\section{References}

Bisyukov, (2000) Restructuring is completed. Was it? Kuzbass. March, 12.

Bisyukov, P.V. (1995). A non-reliable "black gold” Arguments and facts in Kuzbass. № 9 (March), 2.

Bisyukov, P.V., Varshavskaya, E.Ya. (1994). History of two mines closing in Kuzbass, instructive in the way, that similar can happen in other industries and towns. Moscow, $13-14$.

Bogopolsky, I.E., Klimov, S.L., Pokuryakov, V.V. (1999). Coal-mining industry and preliminary results of restructuring. Coal. 12, 35.

Golikov, V. (1990). On condition and perspectives of labor movement development in USSR. Our newspaper. Kemerovo, 2.

Harte S., Grävingholt J., Pleiners H., Schröder H-H. (2003). Geschäfte mit der Macht. Edition Temmen. Bremen. 221.

Kazva, A.M. (2002). Mass protests in social and labor sphere. Collective activities of contracted workers in Russia: sources, problems, and peculiarities. Moscow, 42.

Kozhukhovsky, I. (1999). Reform of coal-mining industry: how it was and will be... Former deputy minister of Mintopenergo on perspectives of reforms in Kuzbass and Russia. Our newspaper. 22, July, 1.

Leskova, N., Tolstikov, A. (1998). Newspaper “Trud” on miners' fates. Plast (Shakhty). № 33. August, 1.

Popov, V. N., Rozhkov, A.A. (2000). Social and economic aspects of coal-mining industry restructuring in Poland. Coal. 4, 45.

Pyatkin, A.M. (2005). Social tension in coal-mining regions: social phenomenon, reality and perspectives. Coal. 9 , $74-75$.

Regions of Russia, (2000). Statistics collection. 2 volumes. Vol. 1. State statistic committee of Russia. Moscow, $147,286,429,512$.

Regions of Russia: Statistics collection. (2001). In 2 volumes. Vol.1. State statistic committee. Moscow.

Rossikhin, V. (1998). Analysis of labor safety and health at coal-mining enterprises in Russia. Iskra (Inta). May, 28.

Salamatin, A.G. (1999). Coal-mining industry in Russia: problems and possibilities of stable development. Coal. 8,6 .

Shadrin, V. (1998) Gordian knot. Iskra. October, 31.

Social conditions and living standards of population in Russia. (2003): Statistics collection. State statistics committee of Russia. Moscow, 348.

State records of Kemerovo region. Fond 1149. List 1. Case 1740, 54.

State records of Prokopyevsk. Fond 31. List 1. Case 315, 32.

State records of the Russian Federation. Fond 10157. List 1. Case 551, 22.

State records of the Russian Federation. Fond 10204. List 2. Case 101, $93-109,132$.

Sturba, E.B. (2009). Formation and realization of national security concept in the Russian Federation in 1992 2004. Abstract of Doctor thesis in History. Moscow, 6 - 7. 